\title{
Challenges and Uncertainty: The Impact of Covid 19 on Segi Seri Group Sdn. Bhd.
}

Mohd Shazali Md. Sharif, Mohd Noor Azmin Akbarruddin, Abdullah Muhamed Yusoff, Nurul Falah Hashim, Putera Mohd Naim Norsalim

To Link this Article: http://dx.doi.org/10.6007/IJARBSS/v11-i16/11218

DOI:10.6007/IJARBSS/v11-i16/11218

Received: 06 July 2021, Revised: 03 August 2021, Accepted: 27 August 2021

Published Online: 25 September 2021

In-Text Citation: (Sharif et al., 2021)

To Cite this Article: Sharif, M. S. M., Akbarruddin, M. N. A., Yusoff, A. M., Hashim, N. F., \& Norsalim, P. M. N. (2021). Challenges and Uncertainty: The Impact of Covid 19 on Segi Seri Group Sdn. Bhd. International Journal of Academic Research in Business and Social Sciences, 11(16), 63-78.

Copyright: (C) 2021 The Author(s)

Published by Human Resource Management Academic Research Society (www.hrmars.com)

This article is published under the Creative Commons Attribution (CC BY 4.0) license. Anyone may reproduce, distribute, translate and create derivative works of this article (for both commercial and non-commercial purposes), subject to full attribution to the original publication and authors. The full terms of this license may be seen at: http://creativecommons.org/licences/by/4.0/legalcode

Special Issue Title: Contemporary Issues in Tourism and Hospitality industry, 2021, Pg. 63 - 78

Full Terms \& Conditions of access and use can be found at http://hrmars.com/index.php/pages/detail/publication-ethics 


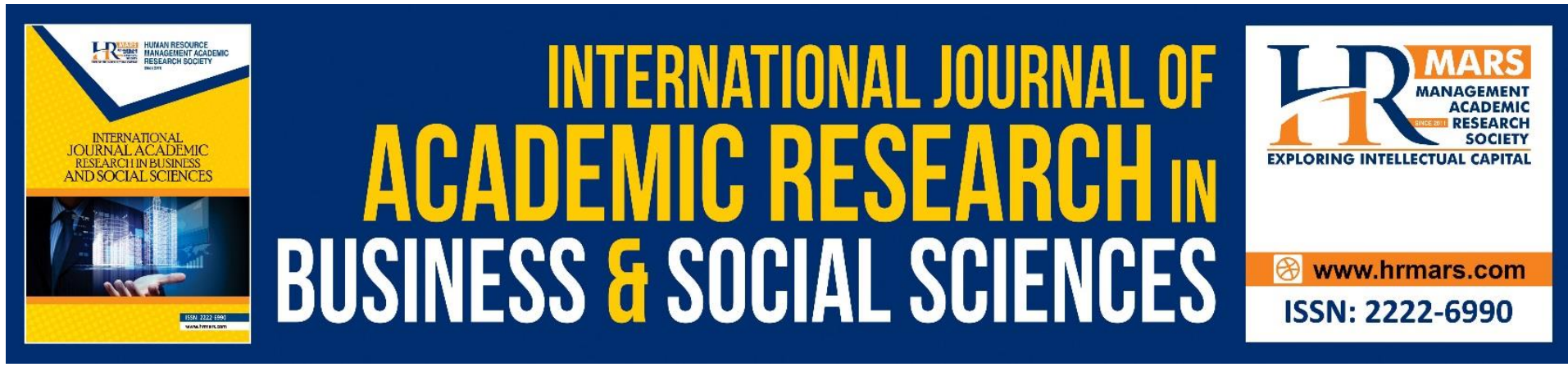

\title{
Challenges and Uncertainty: The Impact of Covid 19 on Segi Seri Group Sdn. Bhd.
}

\author{
Mohd Shazali Md. Sharif ${ }^{1}$, Mohd Noor Azmin Akbarruddin', \\ Abdullah Muhamed Yusoff ${ }^{2}$, Nurul Falah Hashim¹, Putera Mohd \\ Naim Norsalim ${ }^{1}$ \\ ${ }^{1}$ Faculty of Hotel \& Tourism Management, Universiti Teknologi MARA, Puncak Alam Campus \\ Selangor, Malaysia, ${ }^{2}$ Fakulti Hospitaliti Pelancongan dan Kesejahteraan, Universiti Malaysia \\ Kelantan, Malaysia \\ Email:mnazmin@uitm.edu.my
}

\begin{abstract}
Running a business operation has always been associated with certain risk that needs to be constantly monitored to ensure that the risk is under control. In the middle of the present COVID-19 pandemic that has affected various aspects of socioeconomic, the risk and challenges faced by the business organisation just went up a notch higher. The current socioeconomic was unprecedented and due to the drastic measure taken by the government to slow down the spread of the disease, many businesses find themselves struggling to stay afloat as they were unable to run the business as they normally did. Due to the nature that necessitates them to interact directly with the customers, the hospitality industry has received one of the hardest impacts as the pandemic continues. Foodservice sector such as restaurant, small roadside stall, and event management catering has felt the full-frontal brunt of the COVID-19 wave with the latter facing the harshest impact. This study investigated the risk and challenges that a local event management catering company called Seri Segi endured during the COVID-19 pandemic. The study was conducted through 4 months of observation and interviews with some of the employees. The data were analysed using narrative analysis that extracted the key or crucial point of the data. The result showed there were 6 areas of concern that became the challenges for Seri Segi group: branding, cost, customer demand, competition, promotion, and manpower.
\end{abstract}

Keywords: Challenges, Covid-19, Foodservice Establishment, Risk

\section{Introduction}

The new coronavirus epidemic (COVID-19) has swiftly developed into a pandemic following its emergence in Wuhan, China in December 2019 and was formally recognised by the World Health Organization on 11 March 2020, (WHO, 2020). From China to Europe, then from Europe to America, the epicentre of the pandemic changed. More than 177 million individuals were exposed to the virus globally by June 2021, which resulted in more than three million fatalities. The United States, India, Brazil, Russia and the United Kingdom are the countries that possess the largest number of reported positive cases. America, Brazil, Mexico, 
India and the UK are presently ranked as having the highest fatalities (Worldometer, 2021). More positive cases have led to stringent controls and interventions globally (Goyal \& Verma, 2021; Janiak et al., 2021). These limitations and regulations have dramatically influenced people's behaviour. The main activities severely affected by the COVID-19 pandemic are tourism and leisure.

Various steps have led to tourist and recreational activities standing still (Altuntas \& Gok, 2021; Bhaskara \& Filimonau, 2021; Carter et al., 2021; Gonzalez-Torres et al., 2021; Hu et al., 2021) such as shutdowns of restaurants and bars, and international cessation of travel. France and the UK, for instance, declared that restaurants, cafes, fitness centres, theatres and nightclubs around the nation are restricted in order to prevent COVID-19 transmission (Ding \& Li, 2021). Similarly, Turkey temporarily stopped the operation of restaurants, cafes, coffee houses and cafes because of the increasing number of positive cases around the country. In Turkey, delivery services and food takeaways were permitted like they were in the United Kingdom. Therefore, restaurants and cafés have received orders online or via telephone (Altuntas \& Gok, 2021; Orak \& Ozdemir, 2021). Over time, several nations such as Turkey, Germany, and France relieved certain severe measures and limitations due to the decline in the pace of emergence of new cases and relatively controlled viral transmission and economic and societal factors. However, the reality is that COVID-19 pandemic is continuing to necessitate some flexibility in action taken to curb the virus. People have no option but to adjust themselves to live in the world with Covid-19 (Alonso et al., 2020).

Conditions of normal life have considerably changed and a "new normal" has been established which pushed socio-economic adjustments in the lacking of clinical treatments and vaccinations (Al-Omoush et al., 2020; Birtch et al., 2021; Bufquin et al., 2021; Burgos \& Del Pino, 2021; Byrd et al., 2021). During the course of adjusting to the new normal way of life, a growing desire to limit dining out in fear of physical contact with other individuals was noted. As restaurant consumers are worried about and feel cautious with security concerns throughout the food process, they can call for a variety of contactless services from restaurants which are crucial in preventing the transmission of diseases (Brewer \& Sebby, 2021; Brizek et al., 2021; Byrd et al., 2021; Hakim et al., 2021). In addition, governments are demanding and supervising the provision of self-prevention to restaurants and other service companies (Watanabe \& Omori, 2020).

In light of Faulkner (2013) crisis management paradigm, this study showed how negative COVID-19 impacts could be managed by developing measures for recovery and relief activities. In this study, we investigated the challenges faced by Segi Seri Group. This company is a private limited company that is public listed. The main activity of this company is focusing on the foodrelated businesses such as food catering, event management, patient meals in hospitals, food truck and restaurants. Since its establishment in 1995, the company has had tremendous growth, leading them to register their company as public listed in 2003. As one of the leading companies that specialise in food related businesses, Segi Seri enjoy the privilege of being wellknown and therefore sought after by the customers in fulfilling their needs.

However, as the pandemic of Covid 19 started to spread across the country, we are witnessing the struggle of many foods related businesses (Aling \& Abd Malik, 2021; Abdul Rahim, 2020; Ismail, 2020). To curb the spread of Covid 19, the Malaysian government has implemented various forms of movement control order (MCO) since the onset of the pandemic in the country (Alyasa, 2020). This measure has restricted the capability of people to practice their normal way of life which hampers the condition of local businesses and the country's economic condition. Therefore, this study applied the interview and observation methods to identify the 
challenges faced by Segi Seri Groups and recognise important measures and strategies to counter the ongoing financial chaos of the restaurant industry.

\section{Literature Review}

\section{The COVID-19 Impact on Socioeconomic}

Due to the fast propagation of COVID-19 worldwide, travel limitations and full lockdowns throughout most nations were agreed upon at the end of March (Gössling et al., 2020). Varying levels of foreign travel sanctions affected more than 90 percent of the global population. Several nations namely Italy, Spain, India and the United States have placed certain limitations on movement, including restricted air travel and self-imposed house quarantine. The ongoing spread of the COVID-19 outbreak has seriously impacted the worldwide economy. The food business is incredibly susceptible to a lengthy crisis. The fragility of businesses with a certain chance of survival related to the length of the crisis was described by Bartik et al. (2020). They stated that survival chances have fallen considerably from $72 \%$ in the first month of crisis to $15 \%$ after 6 months of ongoing Covid-19 pandemic. This analysis proves that tiny companies are highly susceptible and may rapidly fail from a major catastrophe such as what we are experiencing now (COVID-19).

The restaurant business is probably vulnerable to behavioural shifts in reaction to the pandemic. One of its notable behavioural modifications in the COVID-19 pandemic was selfpreemptive measure such as physical distancing which was deemed essential towards lowering the infection curve (Gupta \& Wong, 2020; Im et al., 2021; Zhang et al., 2021). The food safety officials have also advised the practice of setting a reasonable distance of 1.5 meters in the foodservice establishment. Nonetheless, these key prevention techniques reduced restaurants' operating capacity, leading to an obvious decline in business performance. The Government's down and closure orders are yet another factor for the restaurant sector's financial devastation in the course of this crisis (Foroudi et al., 2021; Goyal \& Verma, 2021; Panzone et al., 2021). These limitations resulted in the fast collapse of enterprises and the losses of billions of dollars. A $\$ 150$ billion rescue plan was implemented in the US to minimise such a loss (Ozili \& Arun, 2020).

Almost all restaurateurs have pursued new possibilities predicated on the altered environment and the new norm caused by COVID-19, but they are quite vulnerable due to external shocks. This would include modifying or adjusting their business strategies to decrease consumer uncertainty with respect to the restaurant sector. For instance, due to the wide area of transmission, COVID-19 has spurred the development and utilisation of delivery services. Because of fear of illness, many individuals choose to remain in their homes willingly by taking self-preventive steps and using food delivery services. China, for example, has experienced a rapid increase in the usage of food delivery service as a way to prevent the spread of the disease, especially in the early 2020 (Xie et al., 2021; Zhao et al., 2021). Similar phenomena can be seen in Malaysia where delivery services such as Food Panda and Grab Food are gaining attraction with more people opting to use the services (Abdullah, 2020; Bernama, 2021; Subramaniam, 2021). In post Covid-19 pandemic, the ability to properly leveraging these new possibilities and consumer habits with a view to minimise the probability of consumer infection will prepare this sector for future external shocks generated by these risk scenarios associated with widespread pandemic. 


\section{Strategies for Financial Recovery}

A worldwide economic and financial crisis has followed the COVID-19 pandemic, overwhelming the 2008-2010 crisis (Brada et al., 2021; Chen \& Yeh, 2021; Gromski et al., 2021). Research has indicated that families prefer to reduce their spending on products and services that are not needed until the economy recovers again (Kim et al., 2021; Kumar \& Shah, 2021; Soon et al., 2021). Therefore, the foodservice sector should adopt measures that decrease anxiety, minimise harm, and enhance financial position (Hakim et al., 2021; Yost et al., 2021). Extreme loss of income from declined demands calls for new approaches in addressing the number of affected profits. Prior studies demonstrated how important it is to evaluate operational performance, profit, liquidity and strategy in case of significant drops of consumer demand (Kizildag, 2015; Kizildag \& Ozdemir, 2017). In order to make the consumers feel comfortable, assured, and safe, restaurants businesses also need to examine health, cleanliness, safety and community rules (Madanoglu et al., 2018). A number of recovery measures must be addressed such as operational stabilisation, financial re-emergence, production of income, job coping mechanisms for the workers impacted, and marketing policies and activities of the marketing community (Foroni et al., 2020; Gerwe, 2021; Hanafiah et al., 2021; Sobaih et al., 2021; Yost et al., 2021).

In a crisis, reducing cash expenses is a crucial financial recovery technique (Gerwe, 2021; Yost et al., 2021). Effective methods to reduce food and drink costs could incorporate improved menu planning, effective procurement practices, more efficient storage options, and enhanced employee training (Madanoglu et al., 2018). One method that appeared to be working was to cut publicity and promotion investment and postpone major expenditure (Chathoth et al., 2006). Another way to decrease expenses was via negotiations with suppliers to reduce the purchase cost of products and with employee/support workers to reduce pay. This would be accomplished by reducing the factor of variable cost. Controlling direct operating costs rather than reducing them is another essential short-term method for financial recovery in severe crisis situations (Linassi et al., 2016). For example, in the case of food and drink, mismanagement in terms of menu design, purchase, receipt, storage, handling, preparation, service, and consumption might erupt. With a planned approach and emphasis on cost management, provision and resources optimisation, harm caused by revenue losses may be minimised (Kim et al., 2021; Song et al., 2021; Yost et al., 2021).

During a crisis, restaurant managers may apply revenue enhancing techniques to reduce harm in parallel with expense reduction. A restaurant can enhance the perceived value of its business to fight the pressures coming from the widespread concern of COVID-19 by implementing a substantial adjustment to the marketing mix and focusing on sanitary and cleanliness (Chang et al., 2021; K. Kim et al., 2021; Soon et al., 2021). Improving food quality and service is the most clear-cut decision. Furthermore, restaurants might provide discounts or other promotional measures to encourage prospective consumers to visit. Taking advantage of the present attention on people's health and the development of their immunity, several restaurants have provided unique anti-COVID meals touted to enhance the immunities of the customers. Besides the above measures, restaurant operators could also arrange for clients who are still frightened to dine with take-away or delivery service. 


\section{Methodology}

\section{Research Design}

The goal of this study was to examine Segi Seri Sdn. Bhd. marketing problems. This research aimed to examine and identify the best method to address most of the organisation's marketing issues. The investigation was conducted using a qualitative method based on corporate observation. The relevant information on the research topic was retained as data. The organisation's phenomena were utilised for the gathering of data, whereas narrative analysis was employed for the summary, interpretation, and presentation of the collected data.

\section{Sample and Data Collection}

The population chosen for this research was the employee of Segi Seri Sdn. Bhd. Convenience sampling was chosen as the sampling technique with the sample size of 10 people. This sample size was based on information power specificity as Malterud et al. (2016) recommended. For the data collection, primary data collection was used. Based on this study, primary data were the data that the researcher obtained directly from the observation on the phenomena of the company, including some question-and-answer sessions to the employees of Segi Seri as stated in research questions. This provided strong data as the data obtained were more accurate. Additionally, pictures and other documents were also included as evidences of this research.

\section{Research Instrumentation}

This study focused on primary data collection in which the data collection was obtained by the staff who faced the challenges.

\section{i. Observation}

The observation was carried out by the researcher who underwent internship at the company of Segi Seri Sdn. Bhd, Shah Alam for 4 months. The observation included all departments available in the organisation by examining the challenges faced by the company during COVID-19 pandemic. During the observation, pictures and other documents were also collected as part of data collection process.

\section{ii. Response and Feedback}

The aim of the study was to investigate the challenges faced by Segi Seri and how they overcame all the challenges. In order to collect detailed information, an interview using semistructured questions was conducted. These open questions were utilised to prevent any partial replies with the concept of discovering rather than prescribing them. Bahasa Malaysia's semi-structured questions version was utilised after a translation was made by the linguistic expert from the English version and translated back to English after the interview due to varying educational levels among the informants. All the answers were recorded and collected as feedback information for the research data.

\section{Result and Analysis}

The data collected from the observation were analysed using narrative analysis. Narrative analysis is a collection of analytic methods for interpreting storied texts or visual data. A common assumption of narrative methods is that people tell stories to help organise and make sense of their lives and their historical accounts are functional and purposeful (Lia Figgou \& Vassilis Pavlopoulos, 2015). By using this specific analysis, the observation was 
recorded based on daily operational activity and matters pertaining to marketing activities in Segi Seri company.

\section{Challenges Faced by Segi Seri}

Based on the question of identifying the factors contributing to the challenges in operating business during the pandemic situation, six themes were identified. The themes derived from the interview and observation were branding, demand and acceptance, cost, promotion, competition, and manpower.

\section{Branding}

Branding is the process of giving an aim to a specific organisation, company, products or services by creating and shaping a brand in consumers' minds. It is a method designed by organisation to assist people in quickly identifying and acknowledging their brand and provide them a reason to decide on their products over the competition by clarifying what this particular brand is and is not (Marion, 2015). From the perspective of branding, Segi Seri Group brand is $100 \%$ owned by Bumiputera company established in 1995 . Presently, it is one of the leading in-house catering services in Selangor. Like all humble beginnings, they started their business by serving buffet - style food and catering. Segi Seri Group was registered and officially launched on March 14th, 2003 by the Ministry of Finance Malaysia and it is currently registered as Bumiputera listed company in Malaysia. As a way to expand the presence and diversify their portfolio, they have expanded their businesses into hospital in-patient meals, corporate event courses organised by the government, private entities, ready-to-eat food, kiosk, wedding, restaurant and many more. The 3 top businesses that lead the sale chart every year are wedding and exclusive venues, hospital in-patient meals, and food truck and restaurant.

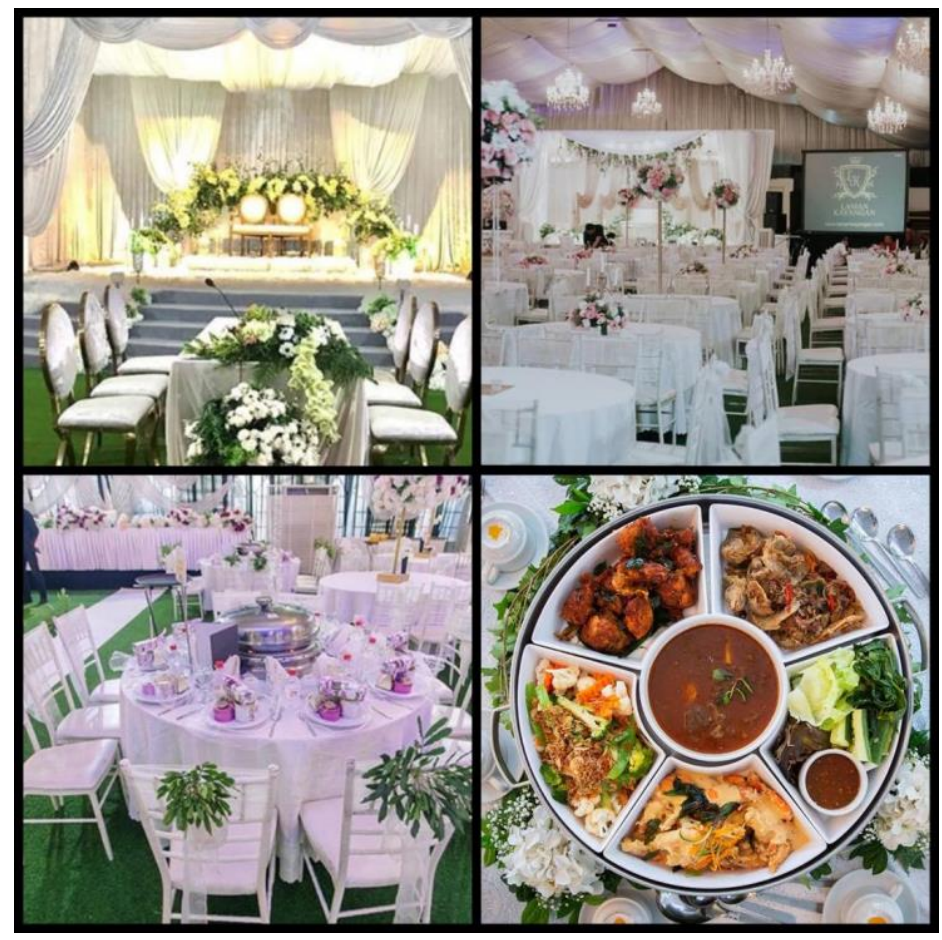

Figure 1: Wedding and exclusive venues Source: Researcher 


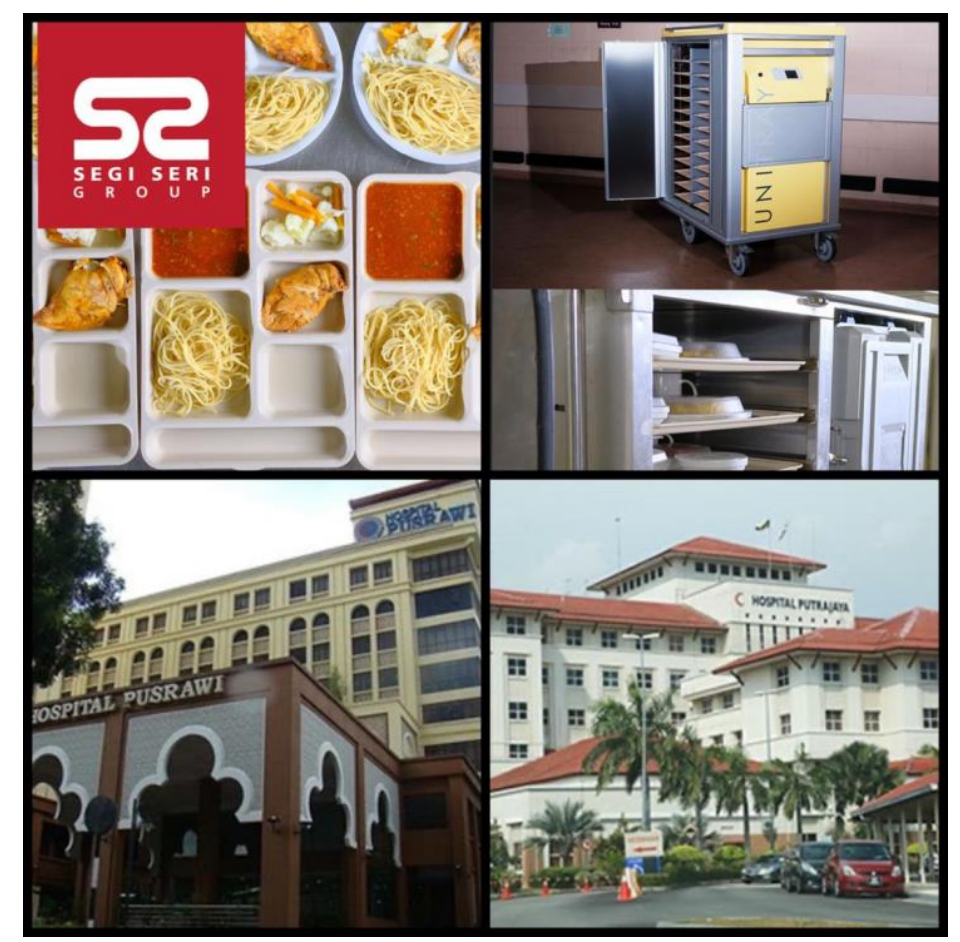

Figure 2: Hospital in-patient meals

Source: Researcher

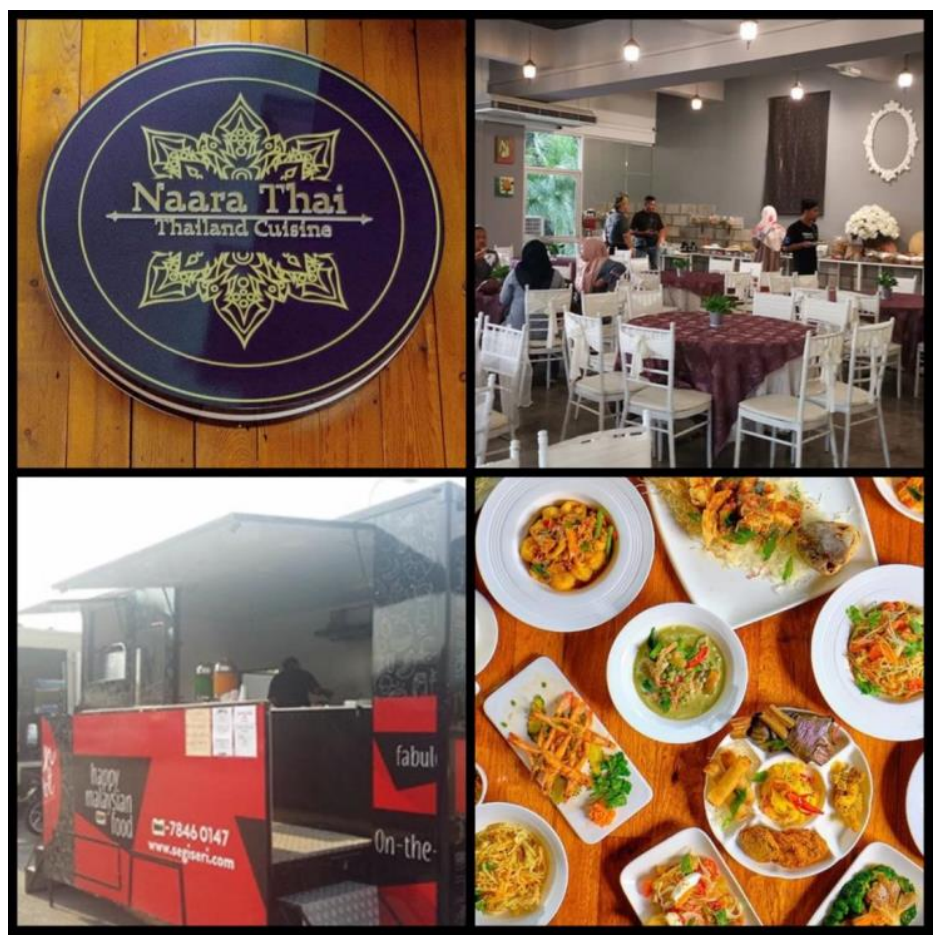

Figure 3: Food truck and restaurant under Segi Seri Source: Researcher

Even though Segi Seri Group is a well-known company, they continuously compete with some new companies with better and innovative branding marketing. Based on the observation and research conducted, the idea of branding that used the classic concept was too old compared to other competitors that have already come out with many new modern ideas and marketing 
strategies that attracted more customers by having a better presentation of branding than Segi Seri Group.

\section{Acceptance and Demand from The Customers}

Recent developments in culture and society are seen to be adjustments towards the demands of consumers. Changing customer tastes and rising technology available and new competitive forms (e.g., shared economy) shape a competitive environment for all companies. Combined with COVID-19 operational constraints, restaurants constantly pursue potential strategies to adapt and remain competitive (Technomic, 2020). In particular, there is a fiercely competitive climate in the foodservice sector that is fuelled by three key developments. The first key development is the customer's preference for food prepared away from home, which has increased steadily over the last two decades (USDA, 2018). The second development focuses on the rise on the usage and accessibility of mobile technology (Statista, 2020) and the last is the emergence of non-traditional forms of competition such as delivery only (Hennesy, 2019). Being one of the most famous event management and catering companies, Segi Seri Group was able to net a profit of around RM2 million in 2019. However, they faced a tough year in 2020 due to the emergence of COVID-19 pandemic and the entrance of new competitors that offer better prices and promotions. Furthermore, during the Covid-19 pandemic, marketing effort to promote as well as to supply the demand was extremely difficult, as the Malaysian government had enforced the Movement Control Order (MCO) from March to the end of August. During the MCO, all events and services were halted until the end of June, forcing the company to close for some time which caused sales to fall. Aside from that, most clients requested a refund and postponed the event during the $\mathrm{MCO}$, which required the company to do more marketing and promotion to entice the customers to postpone their event rather than requesting a refund and losing the client. That was one of the tough challenges for Segi Seri group during the Covid-19 pandemic.

\section{Managing Cost}

From a seller's point of view, the cost is the amount of cash spent in providing products or goods. If the sellers sell their goods at the same price as they cost to supply, they would only achieve the breakeven point but not gain any profit margin. Therefore, the price of a product from the buyer's point of view needs to be calculated carefully. This is the amount charged by a vendor for a product. It includes both the value of the merchandise and the mark-up cost added by the vendor to supply it at a profit.

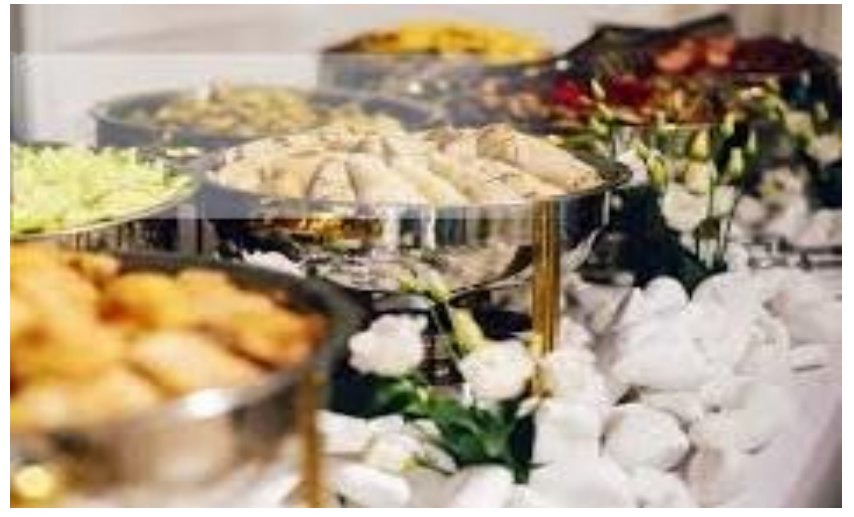

Figure 4: The ingredients and equipment for the catering services Source: Researcher 
In terms of costs, the researcher focused on two major categories: material and fixed costs. Segi Seri Group has a strong capital base and a network of experienced operators for supplying high-quality raw materials, but no company can completely avoid the impact of rising costs and most managers have learned to regulate the effect that inflation has on their current operating costs. Some factors are based on the strategies of competitors in which most executives, particularly those in capital-intensive industries, have paid insufficient attention to how rising capital requirements affect their ability to compete in the future. As a result of research and observation of capital-intensive companies, the researcher found that any organisation can improve its strategic position despite, and even due to, inflation. It is recommended that managers do a strategic analysis to spot the severity of the impact of inflation on their companies' competitive positions, just as on the positions of rival companies. During the interviews, the staff of the company showed their step-by-step action by doing diagnosis and analysis of adjusting cost patterns, just as through the formulation of a strategic solution.

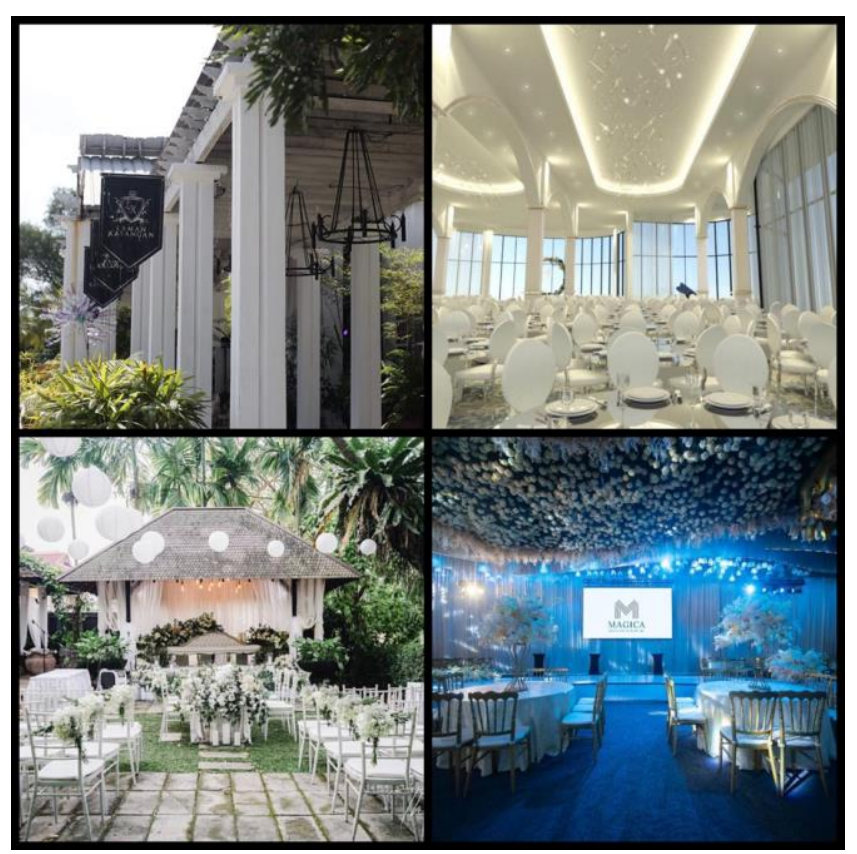

Figure 5: Seri Segi venues that require monthly rent payment Source: Researcher

Aside from that, one of the most difficult aspects for this company is fixed costs. We concentrated on the CODIV 19 pandemic. Seri Segi needs to pay all the venues and company building rent even if the events are not available during the movement control order. This wastes the company's cost and forces them to cover the savings costs for four months.

\section{Promotional Activities}

Promotions correspond with the whole set of activities that communicate the user's merchandise, brand, or service (Kenton, 2021). The idea is to raise people's awareness, attract them, and persuade them to buy certain products over others. Based on observation, there were some promotions carried out by Segi Seri company, such as social media promotion and the distribution of flyers. Social media companies will post on Facebook and Instagram, but the posts will not attract any followers based on the number of likes and engagements. Attracting customers is difficult unless the company spends a lot of money every day on sponsored advertising at a variety of prices. Other than that, the company kept printing the 
flyers and giving them to their customers. According to our observation, this is an old promotional method and majority of the people were nonchalant in keeping the flyers; instead, they chose to throw them away. Furthermore, people generally avoid receiving flyers and brochures in shopping malls or at large events.

\section{Fierce Competition}

According to Crowley and Jordan (2017); Cusumano et al. (2019), competition in business is the contest or rivalry among businesses selling similar products and/or targeting the identical target market to induce more sales, increase revenue, and gain more market share as compared to others. Competition could be a fact of doing business. Businesses face competition in almost every business process, including price, quality, design, sales, and location. Catering services in Selangor face a slew of competitors, particularly for weddings. Generally, competitors will compete for prices based on the venue's size and concept. The taste of the food is also another factor that allows the challenger to compete with other competitors. Based on the observation, there were two major competitors who posed a threat to Segi Seri company namely Bizmillah Catering and Teaffani Catering.

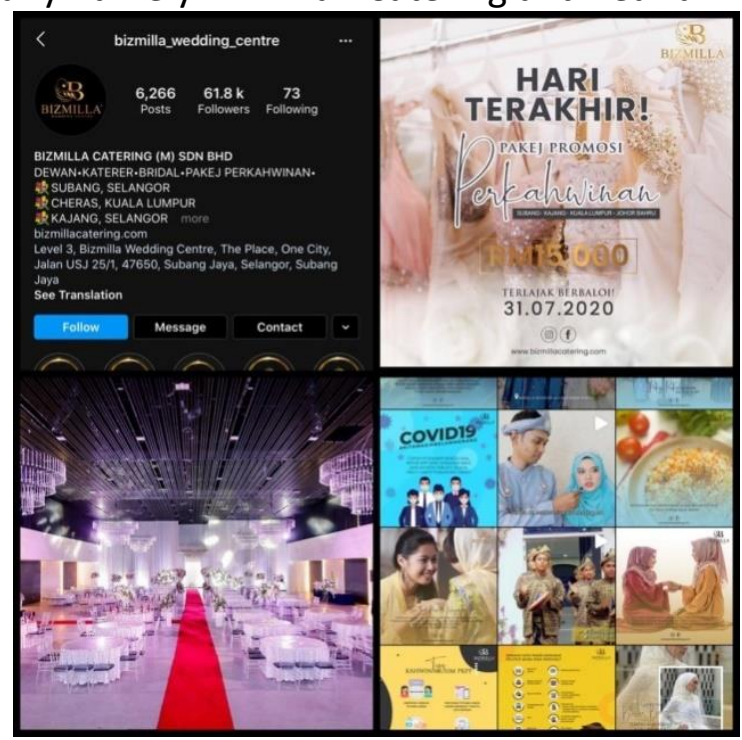

Figure 6: Bizmillah catering promotional resources

Source: Researcher

Bismillah catering is one of the closest Segi Seri competitors. One of the reasons this company is so well-known is that its owner is a Malaysian celebrity. She is one of Segi Seri's competitors due to her popularity. The prices for food services compared were nearly identical, but their promotion was more appealing to the customers. Aside from that, the venue was much nicer with a more modern concept. They usually get a lot of attention from their followers for the promotions they created on social media sites like Facebook and Instagram. The designs of the post and video that they created are more appealing and creative. 


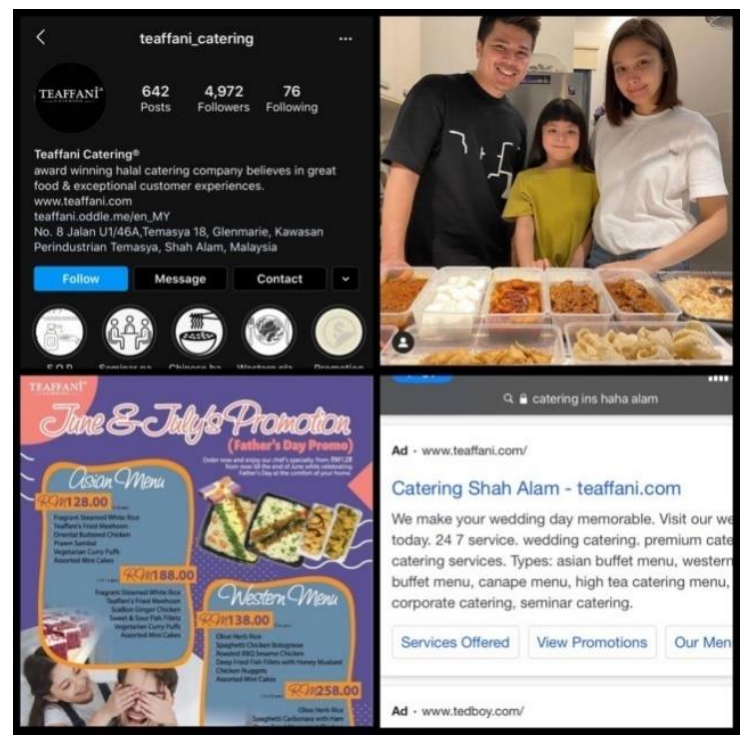

Figure 7: Teaffani catering promotional material

Source: Researcher

The other competitor is Teaffani catering. This is a new business founded in 2019. Even though the company is still in its early stages, the marketing activities in their social media and websites are one of the reasons they could become one of Selangor's most well-known caterer. They always pay for advertising in Google and Instagram to ensure that they are at the top of the search result for 'catering in Selangor.' Aside from that, they always sponsor Malaysian celebrities to promote their services and food, making it more appealing for people to follow them on social media.

\section{Manpower Shortage}

In a company, manpower is needed for selected work to make sure the plan is successful. However, as the COVID-19 pandemic spread through the country, Segi Seri was unable to retain all of its employees due to financial constraints that they faced when they were forced to temporarily halt operations on the order of the government as Malaysia struggled to prevent COVID-19 from spreading further. Due to the measures taken by the government, a lot of catering businesses have to lay off their employees. However, when it was time to begin the operation again, the previous staff were unavailable as some had found other jobs to support their lives.

\section{Conclusion}

According to this research's findings, most Segi Seri clients are from the upper class and corporate sector, and they have a high standard of preference based on their background. Because most ceremonies and events include a culinary menu, clients prefer Malay food for any ceremony or event. Other races appear to be interested in hiring a Malay caterer for their event, but with certain requirements, such as the menu and how the meals are prepared, etc. This appears to be an advantage for the company in grabbing and tackling other races, like having expertise in certain cuisines such as Eastern and Indian food, due to word-of-mouth business. Suppose any researchers wanted to continue this study. In that case, it is suggested that the interview section or questionnaire is conducted to collect more information, input, and recommendations from the clients about the food and services. 


\section{Acknowledgement}

Heartiest appreciation to Mohd Zawir, who have provided the authors with the necessary data for the completion of this article.

\section{Corresponding Author}

Mohd Noor Azmin Akbarruddin

Faculty of Hotel and Tourism Management, Universiti Teknology MARA Selangor, Puncak Alam Campus, Selangor.

Email: mnazmin@uitm.edu.my

\section{References}

Abdul Rahim, N. F. (2020). Pengusaha catering rugi majlis perkahwinan batal. Retrieved from https://www.hmetro.com.my/mutakhir/2020/03/555436/pengusaha-katering-rugimajlis-perkahwinan-batal.

Abdullah, R. (2020). Inisiatif foodpanda. Retrieved from https://www.hmetro.com.my/bisnes/2020/12/655762/inisiatif-foodpanda.

Al-Omoush, K. S., Simón-Moya, V., \& Sendra-García, J. (2020). The impact of social capital and collaborative knowledge creation on e-business proactiveness and organisational agility in responding to the COVID-19 crisis. Journal of Innovation \& Knowledge, 5(4), 279-288. https://doi.org/10.1016/j.jik.2020.10.002

Altuntas, F., \& Gok, M. S. (2021). The effect of COVID-19 pandemic on domestic tourism: A DEMATEL method analysis on quarantine decisions. Int J Hosp Manag, 92, 102719. https://doi.org/10.1016/j.ijhm.2020.102719

Bartik, A. W., Bertrand, M., Cullen, Z. B., Glaeser, E. L., Luca, M., \& Stanton, C. T. (2020). How are small businesses adjusting to COVID-19? Early evidence from a survey (0898-2937).

Bhaskara, G. I., \& Filimonau, V. (2021). The COVID-19 pandemic and organisational learning for disaster planning and management: A perspective of tourism businesses from a destination prone to consecutive disasters. Journal of Hospitality and Tourism Management, 46, 364-375. https://doi.org/10.1016/j.jhtm.2021.01.011

Birtch, T. A., Chiang, F. F. T., Cai, Z., \& Wang, J. (2021). Am I choosing the right career? The implications of COVID-19 on the occupational attitudes of hospitality management students. International Journal of Hospitality Management, 95. https://doi.org/10.1016/j.ijhm.2021.102931

Brada, J. C., Gajewski, P., \& Kutan, A. M. (2021). Economic resiliency and recovery, lessons from the financial crisis for the COVID-19 pandemic: A regional perspective from Central and Eastern Europe. International Review of Financial Analysis, 74. https://doi.org/10.1016/j.irfa.2021.101658

Brewer, P., \& Sebby, A. G. (2021). The effect of online restaurant menus on consumers' purchase intentions during the COVID-19 pandemic. International Journal of Hospitality Management, 94. https://doi.org/10.1016/j.ijhm.2020.102777

Brizek, M. G., Frash, R. E., McLeod, B. M., \& Patience, M. O. (2021). Independent restaurant operator perspectives in the wake of the COVID-19 pandemic. Int J Hosp Manag, 93, 102766. https://doi.org/10.1016/j.ijhm.2020.102766

Bufquin, D., Park, J.-Y., Back, R. M., de Souza Meira, J. V., \& Hight, S. K. (2021). Employee work status, mental health, substance use, and career turnover intentions: An examination of restaurant employees during COVID-19. International Journal of Hospitality Management, 93. https://doi.org/10.1016/j.ijhm.2020.102764 
Burgos, C. R., \& Del Pino, F. J. P. (2021). 'Business can't stop.' Women engaged in prostitution during the COVID-19 pandemic in southern Spain: A qualitative study. Women's Studies International Forum, 86. https://doi.org/10.1016/j.wsif.2021.102477

Byrd, K., Her, E., Fan, A., Almanza, B., Liu, Y., \& Leitch, S. (2021). Restaurants and COVID-19: What are consumers' risk perceptions about restaurant food and its packaging during the pandemic? International Journal of Hospitality Management, 94. https://doi.org/10.1016/j.ijhm.2020.102821

Carter, D., Mazumder, S., Simkins, B., \& Sisneros, E. (2021). The stock price reaction of the COVID-19 pandemic on the airline, hotel, and tourism industries. Finance Research Letters, 102047. https://doi.org/https://doi.org/10.1016/j.frl.2021.102047

Chang, H. S., Capuozzo, B., Okumus, B., \& Cho, M. (2021). Why cleaning the invisible in restaurants is important during COVID-19: A case study of indoor air quality of an openkitchen restaurant. Int J Hosp Manag, 94, 102854.

https://doi.org/10.1016/j.ijhm.2020.102854

Chathoth, P. K., Tse, E. C.-Y., \& Olsen, M. D. (2006). Turnaround strategy: A study of restaurant firms. International Journal of Hospitality Management, 25(4), 602-622.

Chen, H.-C., \& Yeh, C.-W. (2021). Global financial crisis and COVID-19: Industrial reactions. Finance Research Letters. https://doi.org/10.1016/j.frl.2021.101940

Crowley, F., \& Jordan, D. (2017). Does more competition increase business-level innovation? Evidence from domestically focused firms in emerging economies. Economics of Innovation and New Technology, 26(5), 477-488.

Cusumano, M. A., Gawer, A., \& Yoffie, D. B. (2019). The business of platforms: Strategy in the age of digital competition, innovation, and power. Harper Business New York.

Ding, A. W., \& Li, S. (2021). National response strategies and marketing innovations during the COVID-19 pandemic. Bus Horiz, 64(2), 295-306.

https://doi.org/10.1016/j.bushor.2020.12.005

Duarte Alonso, A., Kok, S. K., Bressan, A., O'Shea, M., Sakellarios, N., Koresis, A., Buitrago Solis, M. A., \& Santoni, L. J. (2020). COVID-19, aftermath, impacts, and hospitality firms: An international perspective. Int J Hosp Manag, 91, 102654.

https://doi.org/10.1016/j.ijhm.2020.102654

Faulkner, B. (2013). Towards a framework for tourism disaster management. Routledge.

Foroni, C., Marcellino, M., \& Stevanovic, D. (2020). Forecasting the Covid-19 recession and recovery: Lessons from the financial crisis. International Journal of Forecasting. https://doi.org/10.1016/j.ijforecast.2020.12.005

Foroudi, P., Tabaghdehi, H. S. A., \& Marvi, R. (2021). The gloom of the COVID-19 shock in the hospitality industry: A study of consumer risk perception and adaptive belief in the dark cloud of a pandemic. International Journal of Hospitality Management, 92, 102717. https://doi.org/https://doi.org/10.1016/j.ijhm.2020.102717

Gerwe, O. (2021). The Covid-19 pandemic and the accommodation sharing sector: Effects and prospects for recovery. Technological Forecasting and Social Change, 167. https://doi.org/10.1016/j.techfore.2021.120733

Gonzalez-Torres, T., Rodriguez-Sanchez, J. L., \& Pelechano-Barahona, E. (2021). Managing relationships in the Tourism Supply Chain to overcome epidemic outbreaks: The case of COVID-19 and the hospitality industry in Spain. Int J Hosp Manag, 92, 102733. https://doi.org/10.1016/j.ijhm.2020.102733

Gössling, S., Scott, D., \& Hall, C. M. (2020). Pandemics, tourism and global change: a rapid assessment of COVID-19. Journal of Sustainable Tourism, 29(1), 1-20. 
Goyal, A., \& Verma, P. (2021). Do it yourself effect on restaurants - The pandemic effect: Driven by the fear appeal theory. Journal of Hospitality and Tourism Management, 48, 76-87. https://doi.org/https://doi.org/10.1016/j.jhtm.2021.05.010

Gromski, P. S., Smith, A., Lawlor, D. A., Sharara, F. I., \& Nelson, S. M. (2021). 2008 financial crisis versus 2020 economic fallout: how COVID-19 might influence fertility treatment and live births. Reprod Biomed Online, 42(6), 1087-1096.

https://doi.org/10.1016/j.rbmo.2021.03.017

Gupta, D. D., \& Wong, D. W. (2020). No more "social distancing" but practice physical separation. Canadian Journal of Public Health, 111(4), 488-489.

Hakim, M. P., Zanetta, L. D., \& da Cunha, D. T. (2021). Should I stay, or should I go? Consumers' perceived risk and intention to visit restaurants during the COVID-19 pandemic in Brazil. Food Res Int, 141, 110152. https://doi.org/10.1016/j.foodres.2021.110152

Hanafiah, M. H., Balasingam, A. S., Nair, V., Jamaluddin, M. R., \& Zahari, M. S. M. (2021). Implications of COVID-19 on Tourism Businesses in Malaysia: Evidence from a Preliminary Industry Survey. Asia-Pacific Journal of Innovation in Hospitality and Tourism, 10(1), 81-94.

Hu, H., Yang, Y., \& Zhang, J. (2021). Avoiding panic during pandemics: COVID-19 and tourismrelated businesses. Tourism Management, 86. https://doi.org/10.1016/j.tourman.2021.104316

Im, J., Kim, J., \& Choeh, J. Y. (2021). COVID-19, social distancing, and risk-averse actions of hospitality and tourism consumers: A case of South Korea. Journal of Destination Marketing \& Management, 20. https://doi.org/10.1016/j.jdmm.2021.100566

Janiak, A., Machado, C., \& Turen, J. (2021). Covid-19 contagion, economic activity and business reopening protocols. J Econ Behav Organ, 182, 264-284. https://doi.org/10.1016/j.jebo.2020.12.016

Kim, J., Kim, J., \& Wang, Y. (2021). Uncertainty risks and strategic reaction of restaurant firms amid COVID-19: Evidence from China. Int J Hosp Manag, 92, 102752. https://doi.org/10.1016/j.ijhm.2020.102752

Kim, K., Bonn, M. A., \& Cho, M. (2021). Clean safety message framing as survival strategies for small independent restaurants during the COVID-19 pandemic. Journal of Hospitality and Tourism Management, 46, 423-431. https://doi.org/10.1016/j.jhtm.2021.01.016

Kizildag, M. (2015). Financial leverage phenomenon in hospitality industry sub-sector portfolios. International Journal of Contemporary Hospitality Management.

Kizildag, M., \& Ozdemir, O. (2017). Underlying factors of ups and downs in financial leverage overtime. Tourism Economics, 23(6), 1321-1342.

Kumar, S., \& Shah, A. (2021). Revisiting food delivery apps during COVID-19 pandemic? Investigating the role of emotions. Journal of Retailing and Consumer Services, 62, 102595. https://doi.org/https://doi.org/10.1016/j.jretconser.2021.102595

Linassi, R., Alberton, A., \& Marinho, S. V. (2016). Menu engineering and activity-based costing. International Journal of Contemporary Hospitality Management.

Madanoglu, M., Kizildag, M., \& Ozdemir, O. (2018). Which bundles of corporate governance provisions lead to high firm performance among restaurant firms? International Journal of Hospitality Management, 72, 98-108.

Malterud, K., Siersma, V. D., \& Guassora, A. D. (2016). Sample size in qualitative interview studies: guided by information power. Qualitative health research, 26(13), 1753-1760. https://journals.sagepub.com/doi/10.1177/1049732315617444?url_ver=Z39.882003\&rfr_id=ori\%3Arid\%3Acrossref.org\&rfr_dat=cr_pub\%3Dpubmed\& 
Orak, N. H., \& Ozdemir, O. (2021). The impacts of COVID-19 lockdown on PM10 and SO2 concentrations and association with human mobility across Turkey. Environmental Research, 197, 111018. https://doi.org/https://doi.org/10.1016/j.envres.2021.111018

Ozili, P. K., \& Arun, T. (2020). Spillover of COVID-19: impact on the Global Economy. Available at SSRN 3562570.

Panzone, L. A., Larcom, S., \& She, P.-W. (2021). Estimating the impact of the first COVID-19 lockdown on UK food retailers and the restaurant sector. Global Food Security, 28. https://doi.org/10.1016/j.gfs.2021.100495

Sobaih, A. E. E., Elshaer, I., Hasanein, A. M., \& Abdelaziz, A. S. (2021). Responses to COVID-19: The role of performance in the relationship between small hospitality enterprises' resilience and sustainable tourism development. International Journal of Hospitality Management, 94, 102824. https://doi.org/https://doi.org/10.1016/j.ijhm.2020.102824

Song, H. J., Yeon, J., \& Lee, S. (2021). Impact of the COVID-19 pandemic: Evidence from the U.S. restaurant industry. Int J Hosp Manag, 92, 102702. https://doi.org/10.1016/j.ijhm.2020.102702

Soon, J. M., Vanany, I., Abdul Wahab, I. R., Hamdan, R. H., \& Jamaludin, M. H. (2021). Food safety and evaluation of intention to practice safe eating out measures during COVID19: Cross sectional study in Indonesia and Malaysia. Food Control, 125, 107920. https://doi.org/https://doi.org/10.1016/j.foodcont.2021.107920

Watanabe, T., \& Omori, Y. (2020). Online consumption during the covid-19 crisis: Evidence from Japan. Covid Economics, 38(16), 218-252.

Xie, J., Xu, Y., \& Li, H. (2021). Environmental impact of express food delivery in China: the role of personal consumption choice. Environment, Development and Sustainability, 23(6), 8234-8251.

Yost, E., Kizildag, M., \& Ridderstaat, J. (2021). Financial recovery strategies for restaurants during COVID-19: Evidence from the US restaurant industry. Journal of Hospitality and Tourism Management, 47, 408-412. https://doi.org/10.1016/j.jhtm.2021.04.012

Zhang, L., Wei, W., Line, N. D., \& McGinley, S. (2021). Social distancing: The effect of density and power on restaurant consumers. International Journal of Hospitality Management, 96, 102964. https://doi.org/https://doi.org/10.1016/j.ijhm.2021.102964

Zhao, X., Lin, W., Cen, S., Zhu, H., Duan, M., Li, W., \& Zhu, S. (2021). The online-to-offline (O2O) food delivery industry and its recent development in China. European Journal of Clinical Nutrition, 75(2), 232-237. 